Jurnal Bisnis dan Manajemen, Volume 20, No. 2, September 2019, p. 125-135

\title{
INFLUENCE OF BUSINESS EDUCATION ON ENTREPRENEURIAL INTENTION WITH FEASIBILITY AND ENTREPRENEURIAL SELF- EFFICACY AS INTERVENING VARIABLES
}

\author{
Marlina Deliana ${ }^{1}$, Kusdi Rahardjo ${ }^{2}$, Tri Wulida Afriyanti ${ }^{3}$ \\ 1,2,3 Universitas Brawijaya, Indonesia
}

\begin{abstract}
This study aims to examine the effect of business education on entrepreneurial intention with feasibility and entrepreneurial self-efficacy as the intervening variables. This study was conducted on students of Business study programs, Faculty of Administrative Sciences, Universitas Brawijaya (FIA UB). The number of samples used in this study was 321 students using proportionate stratified random sampling. The questionnaire was used to collect data, and Partial Least Square (PLS) was used for the analysis. We found that; business education has a positive effect on feasibility; business education has a positive effect on entrepreneurial self-efficacy; feasibility has a positive influence on entrepreneurial intention; entrepreneurial self-efficacy has a positive influence on entrepreneurial intention; entrepreneurial self -efficacy has a positive influence on feasibility; and business education has a positive influence on entrepreneurial intention, both directly and indirectly through feasibility and entrepreneurial selfefficacy. The results of this study are expected to provide insight into the feasibility and entrepreneurial self-efficacy so that students can improve these aspects to start a business.
\end{abstract}

Keywords: business education, entrepreneurial intention, entrepreneurial self-efficacy, feasibility.

\section{PENGARUH PENDIDIKAN BISNIS TERHADAP NIAT BERWIRAUSAHA DENGAN VARIABEL INTERVENING FEASIBILITY DAN ENTREPRENEURIAL SELF-EFFICACY}

\begin{abstract}
ABSTRAK
Penelitian ini dilakukan untuk menguji pengaruh pendidikan terhadap keinginan berwirausaha dengan feasibility dan Entrepreneurial self-efficacy sebagai variabel intervening. Mahaiswa Prodi Binis Fakultas Ilmu Administrasi Univeritas Brawijaya merupakan objek dalam penelitian ini. Sampel yang digunakan dalam penelitian ini sebanyak 321 mahasiswa dan teknik pengambilan sampel menggunakan Proportionate stratified random sampling. Kuisioner digunakan dalam pengambilan data dan dianalisis dengan menggunakan Partial Least Square (PLS). Hasil penelitian ini menunjukkan bahwa pendidikan bisnis memiliki pengaruh positif terhadap feasibility, pendidikan bisnis berpengaruh positif terhadap entrepreneurial self-efficacy, feasibility memiliki pengaruh positif terhadap niat berwirausaha, entrepreneurial self-efficacy memiliki pengaruh positif terhadap niat berwirausaha, entrepreneurial self-efficacy memiliki pengaruh positif terhadap feasibility, dan pendidikan bisnis memiliki pengaruh positif terhadap niat berwirausaha baik secara langsung maupun melalui feasibility dan entrepreneurial self-efficacy. Hasil dari penelitian ini diharapkan akan semakin memahami feasibility dan entrepreneurial self-efficay sehingga dapat meningkatkan kemampuan mahasiswa Prodi bisnis FIA UB untuk memulai bisnis.
\end{abstract}

Kata-kata kunci: entrepreneurial self-efficacy, feasibility, niat berwirausaha, pendidikan bisnis,

Korespondensi: Marlina Deliana S.AB. Univeritas Brawijaya. Jln. Veteran Malang, Ketawanggede, Kec. Lowokwaru, Kota Malang, Jawa Timur 65145, Indonesia, Email: deliana_marlina@yahoo.com. 


\section{INTRODUCTION}

Business education, in addition to forming character as professional workers, is also capable of forming someone to become an entrepreneur through an entrepreneurial program. According to Erikson (2003) (as cited in Sanchez, 2013) states that "entrepreneurs can be made" by the entrepreneurial programs, with the different specific educational policies and programs, it is possible to learn to be an entrepreneur. Entrepreneurship has been used as material in business education that can be taught, both at the level of elementary school, junior high school, vocational and general high school, and in higher education. The goal is to change paradigm of student's thinking (Saiman, 2009).

Along with the times and advances in technology and education, the growing interest in entrepreneurship is increase. One of the factors that drives the growing interest in entrepreneurship is entrepreneurship education provided in business education programs. The processes to become entrepreneurs are formed through education (training, workshops, special training, special field education in management, business, and entrepreneurial accounting) (Frinces, 2011).

Education promotes Entrepreneurial Intention because entrepreneurship-relates to knowledge and skills motivate an individual's desire to create a new venture (Cho,1998, as cited in Zhang, Duysters, \& Cloodt, 2014). Education can influence individual intention to make decisions, especially decision to become an entrepreneur.
Someone who has an inadequate level of education results inferiority complex and has a feeling of not being able to achieve establishment of social status (Hakim, 1998). Farrel (1994) (as cited in Jones \& English, 2004) states Students prefer business education that focuses on integrated programs that teach practical skills for starting and expanding business enterprises. The entrepreneurship education program in business education is to give students the knowledge and skill, shape the attitude to act in an entrepreneurial way (Solesvik, 2013).

There are very rare young entrepreneurs among scholars. The research conducted on five state universities in Indonesia found that nearly $75 \%$ of students did not have a clear plan after graduating (Asnadi (2005) as cited in Dharmawati, 2016). Global University Entrepreneurial Spirit Survey (GUESS) data states that $80,3 \%$ students who have graduated prefer to work in the organization (GEM, n.d.). Universities influence growth entrepreneurs in Indonesia. Brawijaya University, one of the kinds that has a role in influencing the young entrepreneurs because of faculty vision is "to become education institution, to develop international scale administrative science that have entrepreneur-minded and smart faculty".

This study aims to analyze the impact of business education on entrepreneurial intention with feasibility and entrepreneurial self-efficacy as variable intervening in students of business study program Administrative science faculty, Brawijaya University. 
Jurnal Bisnis dan Manajemen, Volume 20, No. 2, September 2019, p. 125-135

\section{LITERATURE REVIEW}

Business education is a term that encompasses some methods used to teach students the fundamentals of business practices (inc encyclopedia, n.d.). The business program has a history of ongoing challenges for balancing academic and professional concerns. Bennis \& O'Toole (2005) state that during the $20^{\text {th }}$-century, business education was generally focused on professionalism and relied on practitioners and business people for teaching (Farashahi \& Tajeddin, 2018). The result of study business education for students can apply the basics of business to create a business venture. Entrepreneurship education as a program in business education that given to students can develop knowledge, skill and ability students. Linan (2004) defines entrepreneurship education as the set of training programs within or outside the educational system, trying to increase motivation of participants and intention of participants to perform entrepreneurial action or some patterns that may affect intention such as perception of entrepreneurial desirability and feasibility (Boukamcha, 2015).

This study was to adopt Entrepreneurial Event Shapero's model (SEE). In the model Shapero Entrepreneurial Event (SEE), intentions to start a business derive from perceptions of desirability and feasibility and from a tendency to act upon opportunities (Krueger,Jr, Norris F., Reilly,Mich., 2000). Shapero dan Sokol (1982) (as cited in Hattab, 2014) stated that firm creation is the result of interaction among contextual factors, which would act through their impact on the individual's response.

Shapero and Sokol (1982) (as cited in Boukamcha, 2015) ) give highlight, in their Entrepreneurial Event Model. Knowledge as one of the available resources is related to an individual's perception of feasibility. Entrepreneurship education should improve the perceived feasibility of entrepreneurship (Krueger \& Brazeal,1994, as cited in (Izquierdo \& Buelens, 2011). Entrepreneurial feasibility refers to the degree to which an individual thinks their business is realistic and workable (Emin, 2004, as cited in Boukamcha, 2015). Peterman (2000) (as cited in Wilson, Fiona., Kickul, Jill., Marlino, 2007a) found that participation in an entrepreneurship program significantly increased the perceived feasibility of starting business. Also, those who perceived their entrepreneurship education to be a positive experience showed higher score of perceived feasibility than those who thought their educational experience was negative.

Peterman and Kennedy (2003) (as cited in Farashah, 2013) showed that best practice entrepreneurship programs are expected to increase the perceived feasibility and self-efficacy of participants. Previous studies have suggested that entrepreneurship education should improve the perceived feasibility of entrepreneurship (Krueger \& Brazeal,1994, as cited in Izquierdo \& Buelens, 2011).

The emergence of entrepreneurial intentions in a person is also driven by selfefficacy. Self-efficacy, also known as the social 
Jurnal Bisnis dan Manajemen, Volume 20, No. 2, September 2019, p. 125-135

cognitive theory or social learning theory, is a person's belief that is capable of performing a particular task successfully (Bandura,1977,1997 Lunenburg, 2011b). Malebana \& Swanepoel (as cited in Boukamcha, 2015) ) stated that the importance of entrepreneurial education in selfefficacy enhancement among youth. The concept that uses for explaining humans behavior is selfefficacy. Self-efficacy plays an influential role in determining an individual's choice, level of effort, and perseverance (Chen et al,2004; Mcgee, Peterson, Mueller, \& Sequeira, 2009). The important construct in entrepreneurship research is self-efficacy. However, the lack of agreement over what self-efficacy and how to conceptualize selfefficacy measures poses challenges in entrepreneurship research. There is still unclear whether self-efficacy is focused on tasks or outcomes (Drnovšek, Wincent, \& Cardon, 2010). Therefore, entrepreneurial self-efficacy is used in entrepreneurship research.

Entrepreneurial self-efficacy (ESE) can be defined as the strength of an individual's belief that he or she is capable of successfully performing the roles and tasks of an entrepreneur (Boyd \& Vozikis, 1994 cited in Prabhu, McGuire, Drost, \& Kwong, 2012). Entrepreneurial self-efficacy (ESE) an important predictor to seek entrepreneurial intention development and an individual's success as an entrepreneur. Individuals with high-level selfefficacy tend to highly perceived business opportunities (Krueger et al,2000, as cited in Boukamcha, 2015). A study on US University students in semester 2011/2012 was conducted which states that entrepreneurial self-efficacy students increased significantly at the end of semester (Shinnar, Hsu, \& Powell, 2014).

\section{METHODS}

This research using a quantitative approach. This study was conducted at the Brawijaya University at the Faculty of Administrative Sciences. The sample of this study is a class of 2015-2018 students. A convenience sample of 321 students was set up in this regard. Proportionate stratified random sampling is used as sampling method. Business education as an independent variable uses indicators for measurement of variables adopted from (Fayolle, 2008). Three dimensional composed of 10 items was used. Entrepreneurial intention as the dependent variable adopts an indicator from Chen et.al (1998) used in (Boukamcha, 2015), two dimensional composed of 6 items was used. Then Intervening Variables namely Feasibility use indicators for variable measurements adopted from Emin (2003) used in (Boukamcha, 2015), two dimensional composed of 5 items were used and Entrepreneurial self-efficacy using indicators for measurement of variables adopted from (Chen, Greene, \& Crick, 1998), two dimensions composed of eight items were used. To collect the data using a questionnaire that distribute to 321 research respondents. The data analysis was conduct using Partial least Square (PLS). Figure 1 shows the research of this model. 
Jurnal Bisnis dan Manajemen, Volume 20, No. 2, September 2019, p. 125-135

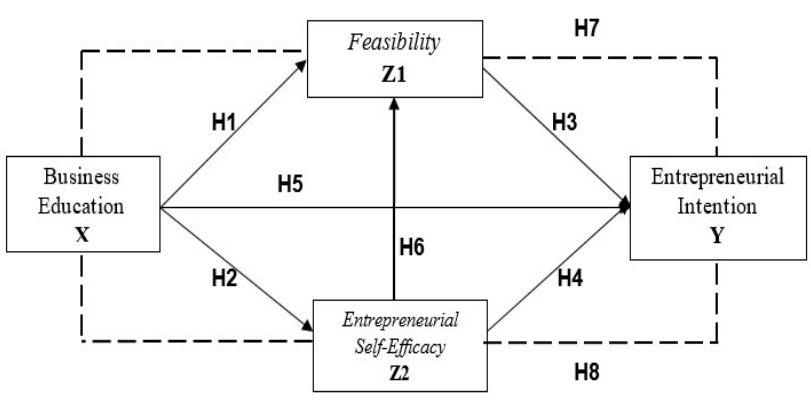

Figure 1. Research Model

\section{RESULTS AND DISCUSSION}

PLS analysis techniques use two stages to assess the fit of the model from a research model. The first is evaluating the outer model or measurement model. The second stage, evaluation of the inner model or structural model. The outer model has three criteria, namely convergent validity, discriminant validity, and composite reliability. This assessment uses a minimum loading factor of 0.5. Convergent validity can be seen at the outer loading. The value of outer loading of each indicator can be seen in table.

Table 1 points out that all values of factors are loading from indicators of business education (X), Feasibility (Z1), Entrepreneurial self-efficacy (Z2), and intention to entrepreneurship (Y) greater than 0.5 . This shows that the indicators are valid.
Table 1. Outer Loading

\begin{tabular}{ccccc}
\hline & $\begin{array}{c}\text { Original } \\
\text { Sample } \\
(\mathbf{O})\end{array}$ & $\begin{array}{c}\text { Standard } \\
\text { Deviation } \\
\text { (STDEV) }\end{array}$ & $\begin{array}{c}\mathbf{T} \\
\text { Statistics } \\
(\mid \mathbf{O} / \\
\text { Sterr } \mid)\end{array}$ & $\begin{array}{c}\mathbf{p -} \\
\text { value }\end{array}$ \\
\hline $\mathbf{X 1 . 1}<-\mathbf{X}$ & 0.867 & 0017 & 50836 & 0000 \\
$\mathbf{X 1 . 2}<-\mathbf{X}$ & 0.857 & 0022 & 38762 & 0000 \\
$\mathbf{X 1 . 3}<-\mathbf{X}$ & 0.878 & 0.014 & 61,898 & 0,000 \\
$\mathbf{Y 1 . 1}<-\mathbf{Y}$ & 0.963 & 0.005 & 179,388 & 0,000 \\
$\mathbf{Y 1 . 2}<-\mathbf{Y}$ & 0.964 & 0.006 & 168,813 & 0,000 \\
$\mathbf{Z 1 . 1}<-\mathbf{Z 1}$ & 0.908 & 0.012 & 78,960 & 0,000 \\
$\mathbf{Z 1 . 2}<-\mathbf{Z 1}$ & 0.902 & 0.012 & 78.308 & 0.000 \\
$\mathbf{Z 2 . 1}<-\mathbf{Z 2}$ & 0.878 & 0.015 & 57839 & 0000 \\
$\mathbf{Z 2 . 2}<-\mathbf{Z 2}$ & 0.848 & 0028 & 30832 & 0000 \\
\hline Source: processed data (2019) & &
\end{tabular}

Testing the Inner Model or the structural model was conducted to see correlation between the construct of the significance and value $\mathrm{R}$-square for the construct dependent t-test and significance of coefficient parameters of structural lines.

Table 2. Value of R-Square

\begin{tabular}{cc}
\hline Variable & R Square \\
\hline $\mathrm{Z} 1$ & 0.5115 \\
$\mathrm{Z} 2$ & 0.3003 \\
$\mathrm{Y}$ & 0.5241 \\
\hline
\end{tabular}

Source: processed data (2019)

Table 2 shows the R-square value for the variable feasibility (Z1) which is influenced by the business education variable $(\mathrm{X})$ obtained at 0,5115 . The R-Square value shows that $51,15 \%$ of the Feasibility (Z1) variable can be influenced by business education variables (X) and Entrepreneurial Self-Efficacy (Z2), while the remaining $48,85 \%$ is affected by other variables. Then the R-square value of Entrepreneurial selfefficacy (Z2) is 0,3003, which indicates that $30,30 \%$ can be influenced by business education (X) while the remaining $69,97 \%$ is affected by outside variables of those studied. Likewise, the value of R-Square entrepreneurial intention 
Jurnal Bisnis dan Manajemen, Volume 20, No. 2, September 2019, p. 125-135

variable is 0,5241 which indicates that $52,41 \%$ of entrepreneurial intention is influenced by business education variables (X), Feasibility (Z1), and variables Entrepreneurial self-efficacy (Z2) while the remaining $47,59 \%$ is influenced by other variables outside the research model. Therefore, value predictive relevance $\left(Q^{2}\right)$ can be found based on the value in table 2 .

$$
\begin{aligned}
\text { Value } \mathrm{Q}^{2}= & 1-\left(1-\mathrm{R}^{2}\right)\left(1-\mathrm{R}^{2}\right)\left(1-\mathrm{R}^{2}\right) \\
\text { Value } \mathrm{Q}^{2}= & 1-(1-0.5115) \times(1-3003) \times(1 \\
& -0.5241=0,8373
\end{aligned}
$$

The results of the calculation show that $\mathrm{Q}^{2}$ are 0,8373 , which means the diversity of the research data can be explained by the structural model of $83,73 \%$, while the remaining $16,27 \%$ is explained by other factors outside the model.

Table 3. Path Coefficient

\begin{tabular}{cclll}
\hline & $\begin{array}{c}\text { Original } \\
\text { Sample } \\
(\mathbf{O})\end{array}$ & $\begin{array}{c}\text { Standard } \\
\text { Deviation } \\
(\text { STDEV) }\end{array}$ & $\begin{array}{c}\text { T Statistics } \\
(\mid \mathbf{O} /\end{array}$ & p-value \\
STERR $\mid)$ & \\
\hline $\mathbf{X ~ - > ~ Z 1 ~}$ & 0.211 & 0.046 & 4,570 & 0,000 \\
$\mathbf{X}->\mathbf{Z 2}$ & 0.548 & 0.059 & 9,242 & 0,000 \\
$\mathbf{Z 1 ~}->\mathbf{Y}$ & 0.407 & 0.065 & 6,263 & 0,000 \\
$\mathbf{Z 2}->\mathbf{Y}$ & 0.269 & 0.067 & 4,033 & 0,000 \\
$\mathbf{X}->\mathbf{Y}$ & 0.153 & 0.059 & 2.614 & 0.009 \\
$\mathbf{Z 2}->\mathbf{Z 1}$ & 0.578 & 0.042 & 13,688 & 0,000 \\
\hline
\end{tabular}

Source: processed data (2019)

Table 3 shows the results of hypothesis testing indicate that the relationship of business education variables with Feasibility shows the path coefficient value of 0.211 with t-statistic of $4,570>$ 1,960. These results indicate that business education variable has a positive and significant effect on the feasibility study of FIA UB's business program students, so Hypothesis $\mathbf{1}$ is accepted. This means that the better the business education received by students, the better and will have an impact on Feasibility. The results of this study support previous research conducted by Boukamcha (2015) conducted in the CEFE program training (Creation des Entrepreneurs et Formation des Entrepreneurs) in Tunisia against 80 business school students, stating that there is a positive and significant relationship between training education on Feasibility. (Liñán et al., 2011) conducted research on 354 economics and business students at the University of Seville Spain. Education has an affects feasibility student (Liñán, Rodríguez-Cohard, \& Rueda-Cantuche, 2011).

The relationship of business education variables with entrepreneurial self-efficacy shows the path coefficient value of 0,548 with t-statistic value of 9,242>1,960. These results indicate that business education variable positively and significantly influences entrepreneurial selfefficacy, so Hypothesis $\mathbf{2}$ is accepted. This shows that the better the business education provided will have an impact on the higher Entrepreneurial SelfEfficacy. Entrepreneurial self-efficacy determines how a person feels, thinks, motivates himself and behaves to carry out entrepreneurial tasks. Someone who has high Entrepreneurial Selfefficacy will usually be more motivated in developing (intention) towards desires action. The results of this study support previous research by Wilson, Kickull and Marlino (2007) conducted on students at the university in the region state of US (New England, Illinois, California, Texas / Florida / Tennessee) from November 2003 to April 2004 stating that there is a relationship between educations towards Entrepreneurial self-efficacy. 
Jurnal Bisnis dan Manajemen, Volume 20, No. 2, September 2019, p. 125-135

Shinnar, Hsu and Powell (2014) conducted study on US University students in semester 2011/2012, stating that entrepreneurial self-efficacy students increased significantly at the end of semester. Boukamcha (2015) conducted research on students who participated in CEFE (Creation des Entrepreneurs et Formation des Entrepreneurs) in Tunisia stating that training education influenced Entrepreneurial Self-Efficacy.

The results of the third hypothesis based on table 3 show that Feasibility has a positive and significant effect on entrepreneurial intentions with a path coefficient value of 0,407 and t-statistic value $6,263>1,960$. These results indicate that the variable Feasibility has a positive and significant effect on entrepreneurial intentions, so Hypothesis 3 is accepted. Someone who has high feasibility can influence the intention of entrepreneurship in a person. Feasibility shows a person's skills and abilities in creating new businesses that are realistic and workable. Linan et al. (2011) stated that Feasibility is positively related to the intention of student entrepreneurship. Hattab (2014) conducted a study on students British University in Egypt from three faculties (engineering, business studies, and computer science) which states that feasibility influence the desire to build a new business.

The results of the fourth test on table 3 show that the variable Entrepreneurial Self-Efficacy positively affects entrepreneurial intentions with a path coefficient of 0,269 with t-statistic value of $4,033>1,960$. This result means that Entrepreneurial self-efficacy has a positive and significant influence on the intention of entrepreneurship in business students of FIA UB's, so Hypothesis 4 is accepted. This shows that the higher a person's Entrepreneurial Self-Efficacy will affect a student's entrepreneurial intentions. Entrepreneurial self-efficacy is a development of theory Self-efficacy proposed by Bandura. Entrepreneurial self-efficacy ensure how a person thinks, feels, motivates himself and behaves to carry out entrepreneurial tasks. Someone who has high Entrepreneurial Self-efficacy will usually be more motivated in developing (intention) towards desires. The results of this study support the previous research conducted by Wilson, Kickul \& Marlino (2007), stating that there is a relationship between Self-efficacy towards Entrepreneurial Intention in male students. Then, Izquierdo and Buelens (2008) state that Entrepreneurial Intention is influenced by Entrepreneurial Self-Efficacy. Then, McGee et al. (2009) stated that ESE had a positive relationship with entrepreneurial intention. Farashah (2013) states that Self-efficacy affected Entrepreneurial Intention.

The results of the sixth hypothesis testing based on table 3 show that the relationship between business education variables has an influence on entrepreneurial intentions with a path coefficient value of 0,153 with t-statistic value 2,614 > 1,960. This result means that business education has a positive and significant influence on entrepreneurial intentions, so Hypothesis 5 is accepted. Business education received by FIA UB students proved to influence the students of FIA UB entrepreneurship intentions. Based on the business education obtained, the intention of a 
Jurnal Bisnis dan Manajemen, Volume 20, No. 2, September 2019, p. 125-135

student is getting stronger and influence to create a new business. This study has a result supported by previous research by (Wu \& $\mathrm{Wu}, 2008)$ stating that respondents who graduated from bachelor and diploma were more interested in starting a business. Solesvik (2013) states that someone who participates in entrepreneurship programs in business education tends to be entrepreneurs. Farashah (2013) states that someone who participates in the EET (Entrepreneurship Education Training) program is more willing to start his own business. Hattab (2014) also confirmed that entrepreneurship education influence the entrepreneurial intentions of students at universities in British University Egypt. Also, (Mohamad, Noorkartna; Lim, Hock Eam; Yusof, Norhafeza; Soon, 2015) stated that entrepreneurial graduates have a stronger desire to become entrepreneurs than those who are not entrepreneurial graduates. Then Gelaidan and Abdullateef (2017) conducted research on students in Malayasia and stated that education positively and significantly has relationship with the intention of entrepreneurship (Gelaidan, Hamid Mahmood; Abdullateef, 2017).

The results of testing the sixth hypothesis based on table 3, Entrepreneurial self-efficacy variable and the variable Feasibility show the path coefficient value of 0,578 with t-statistic value $13,668>1,960$. This shows that Entrepreneurial Self-Efficacy positively influences the Feasibility of FIA UB students, so Hypothesis 6 is accepted. Entrepreneurial self-efficacy ensure how a person feels, thinks, motivates himself and behaves to carry out entrepreneurial tasks. Individual who thinks their business realistic and workable refers to feasibility. Entrepreneurial Self-Efficacy Student-owned encourages students to have the ability to create innovative new ideas in starting a business by paying attention to risks that might be faced so that the idea of a business plan is possible to run. This result supports previous research conducted by Boukamcha (2015) researching students who participated in CEFE (Creation des Entrepreneurs et Formation des Entrepreneurs) in Tunisia, stating that Entrepreneurial self-efficacy has a significant relationship with feasibility.

Table 4. Results of Indirect Influence

\begin{tabular}{lcccccccc}
\hline Variable & \multicolumn{2}{c}{$\begin{array}{c}\text { Indirect } \\
\text { coefficient }\end{array}$} & \multicolumn{2}{c}{ standard } & Indire & s.e & t- & p \\
& $\mathbf{X} \rightarrow \mathbf{Z}$ & $\mathbf{X} \rightarrow$ & $\mathbf{X} \rightarrow$ & $\mathbf{X} \rightarrow$ & $\begin{array}{c}\text { ct } \\
\text { coeffic }\end{array}$ & $\begin{array}{c}\text { Sob } \\
\text { el }\end{array}$ & $\begin{array}{c}\text { stati } \\
\text { stic }\end{array}$ & \\
& $\mathbf{1} \rightarrow \mathbf{Y}$ & $\mathbf{Z 2}$ & $\mathbf{Z 1}$ & $\mathbf{Z 2}$ & ient & & & \\
\hline $\mathrm{X}, \mathrm{Y} 1, \mathrm{Y}$ & 0.21 & 0.40 & 0.04 & 0.06 & 0.08 & 0.02 & 3.65 & 0.00 \\
$\mathrm{X}, \mathrm{Y} 2, \mathrm{Y}$ & 0.54 & 0.26 & 0.05 & 0.06 & 0.14 & 0.04 & 3.67 & 0.00 \\
\hline
\end{tabular}

Source: processed data (2019)

The results of the seventh hypothesis based on Table 4 the relationship between business education variables towards entrepreneurial intention through Feasibility has an indirect path coefficient of 0,086 with t-statistic 3,659 > 1,960. This shows that business education will increase Feasibility student which results in the emergence of intentions for FIA UB students so that Hypothesis 7 is accepted. The knowledge possessed by students is obtained through business education that is undertaken, either through the theory or business practice. The knowledge possessed by someone will cause feasibility in a person. The results of this study support previous 
Jurnal Bisnis dan Manajemen, Volume 20, No. 2, September 2019, p. 125-135

research conducted by Farashah (2013), stating that the completion of an entrepreneurial program increases the desire to have a business with Feasibility as a variable of the significant predictor. Also, Hattab (2014) shows that there is a positive relationship between education and feasibility which results in the intention of entrepreneurship in students of British Egypt University.

The results of the eighth hypothesis based on table 4 show that the relationship between business education variables towards entrepreneurial intentions through Entrepreneurial Self-Efficacy has an indirect path coefficient of 0.147 with t-statistic value $3,677>1,960$. This shows that business education that was given to students of FIA UB will increase the Entrepreneurial Self-Efficacy of students, which will result in the emergence of entrepreneurial intentions so that Hypothesis 8 is accepted. Business education provided by lecturers is proven to be able to build Entrepreneurial Self-Efficacy for FIA UB students. Shinnar, Hsu, and Powell (2014) explain that education can strengthen one's entrepreneurial self-efficacy. Entrepreneurial knowledge will improve the ability to identify opportunities from participants and positively enhance their entrepreneurial self-efficacy (McStay (2008) as cited in Boukamcha, 2015). The results of this study support previous research by Wilson, Kickull and Marlino (2007) was conducted in the region state of US (New England, Illinois, California, Texas / Florida / Tennessee) from November 2003 to April 2004 stating that providing access to entrepreneurship education has essential in fueling the pipeline of aspiring entrepreneurs, because education plays the strong role in raising their levels of self-efficacy and their interest to build their own business.

\section{CONCLUSION}

Based on the problems that have been formulated, the results of this study, and testing of the hypothesis that has been carried out, all proposed hypotheses are accepted. Business education affects feasibility positively and significantly. Business education affects entrepreneurial selfefficacy positively and significantly. The relationship between feasibility and entrepreneurial intention is positive and significant. Entrepreneurial self-efficacy relates to entrepreneurial intention positively and significantly. Business education has a positive and significant effect on the intention of entrepreneurship. Besides, business education has a positive and significant relation to entrepreneurial intentions through feasibility. Business education positively and significantly influence the entrepreneurial intentions through Entrepreneurial self-efficacy.

To increase understanding of business education students, it is essential to growing their feasibility and entrepreneurial self-efficacy. So they will be more confident in creating business opportunities. The results of this study can be used as a reference for further researchers to develop this research by considering other variables so that further research can have different perspective. 
Jurnal Bisnis dan Manajemen, Volume 20, No. 2, September 2019, p. 125-135

\section{REFERENCES}

Boukamcha, F. (2015). Impact of training on entrepreneurial intention: an interactive cognitive perspective. European Business Review, 27(6), pp.593-616. https://doi.org/10.1108/EBR-122014-0090.

Chen, C. C., Greene, P. G., \& Crick, A. (1998). Does entrepreneurial self-efficacy distinguish entrepreneurs from managers? Journal of Business Venturing, 13(4), pp.295-316. https://doi.org/10.1016/S0883-9026(97)00029-3.

Dharmawati, H. D. M. (2016). No Title. Jakarta: Rajawali Pers.

Drnovšek, M., Wincent, J., \& Cardon, M. S. (2010). Entrepreneurial self-efficacy and business start-up: Developing a multi-dimensional definition. International Journal of Entrepreneurial Behaviour and Research, 16(4), 329-348. https://doi.org/10.1108/13552551011054516.

Farashah, A. D. (2013). The process of impact of entrepreneurship education and training on entrepreneurship perception and intention: Study of educational system of Iran. Education and Training, 55(8-9), 868-885. https://doi.org/10.1108/ET-04-2013-0053

Farashahi, M., \& Tajeddin, M. (2018). Effectiveness of teaching methods in business education: A comparison study on the learning outcomes of lectures, case studies and simulations. International Journal of Management Education, 16(1), 131-142. https://doi.org/10.1016/j.ijme.2018.01.003.

Fayolle, A. (2008). Entrepreneurship Education at A Crossroads: Towards a More Teaching Field. Journal of Entreprising Culture, 16, 325-337.

Frinces, H. Z. (2011). Be an Entrepreneur. Yogyakarta: Graha Ilmu.

Gelaidan, Hamid Mahmood; Abdullateef, A. O. (2017). Entrepreneurial Intentions of Business Students in Malaysia: the Role of Self-Confidence and Educational and relation support. Journal of Small Business and Entreprise Development, 24(1).

GEM. (n.d.). Global Entrepreneurship Reaserch Association. Retrieved from https://www.gemconsotium.org.

Hakim, R. (1998). Dengan Wirausaha Menepis Krisis. Jakarta: PT.Elex Media Kompetindo.

Hattab, H. W. (2014). Impact of Entrepreneurship Education on Entrepreneurial Intentions of University Students in Egypt. Journal of Entrepreneurship, 23(1), pp. 1-18. https://doi.org/10.1177/0971355713513346.

inc encyclopedia. (n.d.). Business Education. Retrieved from inc encyclopedia website: https://www.inc.encyclopedia/businesseducation.html.

Izquierdo, E., \& Buelens, M. (2011). Competing models of entrepreneurial intentions: the influence of entrepreneurial self-efficacy and attitudes. International Journal of Entrepreneurship and Small Business, 13(1), 75,pp.1-30 https://doi.org/10.1504/IJESB.2011.040417.

Jones, C., \& English, J. (2004). A contemporary approach to entrepreneurship education. Education + Training, 46, pp. 416-423. https://doi.org/10.1108/00400910410569533.

Krueger,Jr, Norris F., Reilly,Mich., C. A. L. (2000). Competing Models of Entrepreneurial Intentions. Journal of Business Venturing, 15, pp. 411-432.

Liñán, F., Rodríguez-Cohard, J. C., \& Rueda-Cantuche, J. M. (2011). Factors affecting entrepreneurial intention levels: A role for education. International Entrepreneurship and Management Journal, 7(2), pp. 195-218. https://doi.org/10.1007/s11365-0100154-z.

Lunenburg, F. C. (2011). Self-efficacy in the workplace: Implications for Motivation and Performance. International Journal of Management, Business, and Administration, 14(1), $1-6$.

Mcgee, J. E., Peterson, M., Mueller, S. L., \& Sequeira, J. M. (2009). Entrepreneurial self-efficacy: Refining the measure. Entrepreneurship: Theory and Practice, 33(4),pp.965-988. https://doi.org/10.1111/j.15406520.2009.00304.x.

Mohamad, Noorkartna; Lim, Hock Eam; Yusof, Norhafeza; Soon, J. J. (2015). Estimating The Effect of Entrepreneur Education on Graduates' Intention To Be Entrepreneurs. Education + Training, 57(8/9), pp. 1-25.

Prabhu, V. P., McGuire, S. J., Drost, E. A., \& Kwong, K. K. (2012). Proactive personality and entrepreneurial intent. International Journal of Entrepreneurial Behavior \& Research, 18(5), 559586. https://doi.org/10.1108/13552551211253937

Saiman, L. (2009). No Title (2nd ed.). Jakarta: Salemba Empat.

Sanchez, J. C. (2013). The Impact of an Entrepreneurship Education Program on Entrepreneurial Competance and Action. Journal of Small Business Management, 447-465. https://doi.org/10.1111/jsbm. 12025.

Shinnar, R. S., Hsu, D. K., \& Powell, B. C. (2014). Selfefficacy, entrepreneurial intentions, and gender: Assessing the impact of entrepreneurship education longitudinally. International Journal of Management Education, 12(3), pp. 561-570. https://doi.org/10.1016/j.ijme.2014.09.005. 
Jurnal Bisnis dan Manajemen, Volume 20, No. 2, September 2019, p. 125-135

Solesvik, M. Z. (2013). Entrepreneurial motivations and intentions: Investigating the role of education major. Education and Training, 55(3), pp. 253271. https://doi.org/10.1108/00400911311309314.

Wilson, Fiona., Kickul, Jill., Marlino, D. (2007). Gender, Entrepreneurial Self-Efficacy, and Entrepreneur Career Intentions: Implications for Entrepreneurship Education. Entrepreneurship Theory and Practice, pp. 387-405.

$\mathrm{Wu}, \mathrm{S}$. , \& $\mathrm{Wu}, \mathrm{L}$. (2008). The impact of higher education on entrepreneurial intentions of university students in China. Journal of Small Business and Enterprise Development, 15(4), pp.752-774.

https://doi.org/10.1108/14626000810917843

Zhang, Y., Duysters, G., \& Cloodt, M. (2014). The role of entrepreneurship education as a predictor of university students' entrepreneurial intention. International Entrepreneurship and Management Journal, 10(3),pp.623-641. https://doi.org/10.1007/s11365-012-0246-z. 